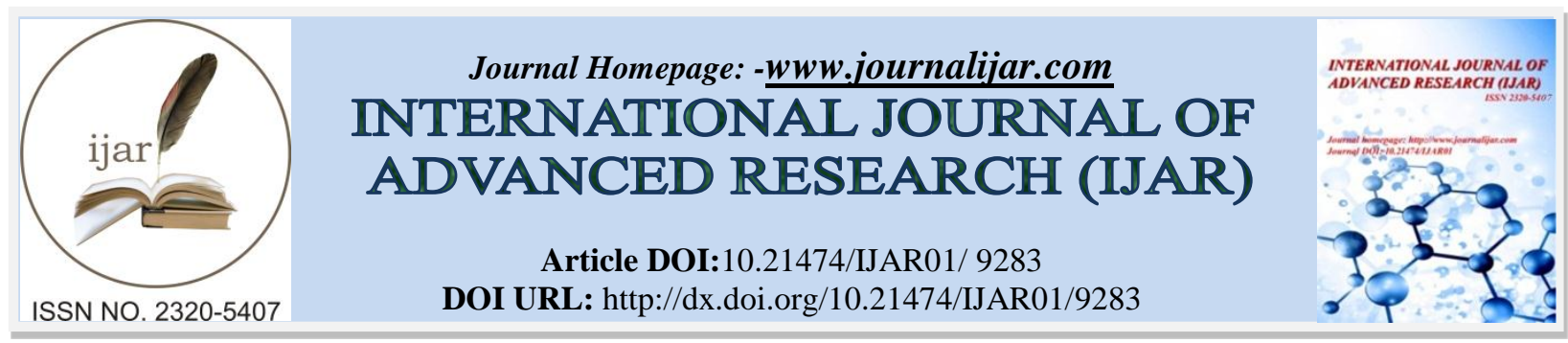

RESEARCH ARTICLE

\title{
SOCIAL RESPONSIBILITIES OF BUSINESS ENTITIES: A BASIC STEP FOR POVERTY ALLEVIATION.
}

Edna P. Yumol.

CPA,PhD,Kalinga State University,Tabuk City ,Kalinga,Philippines.

\section{Manuscript Info}

Manuscript History

Received: 15 April 2019

Final Accepted: 17 May 2019

Published: June 2019

Key words:-

Business , Corporate

Responsibilty,Scholarship sponsorship by Business Establishment, Kalinga State University.

\section{Abstract}

The study made use of a descriptive method to assess the practices of the business sector of their responsibilities and participation to their internal and external environment in the two adjacent barangays of Tabuk City, Philippines. The study described the data gathered from the respondents. There were 35 business establishments participated in the study through their responses to the questionnaire. The objectives are: To determine the profile of the respondents; to determine the level of practices of business owners toward their social responsibilities to their employees and the consumers; to the level of participation of the business establishments; and to identify what project do respondents want to extend to the community.

The study found that: 1 . Most of the businesses capital is categorized as small capital. Fifty-one $51 \%$ or 18 business owners have small capital, $46 \%$ or 16 of the businesses (the respondents) have an average income. The practice of the businesses on the social responsibilities towards their employees was described as" often practice; and there is no significant relationship between the tax due and the practice of the respondents on their social responsibilities; As to the assessment of the respondents for their participation towards their responsibilities to the

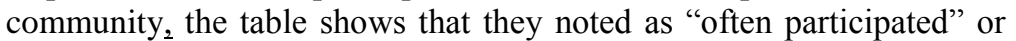
most of the respondents noted that they often practice the different responsibilities towards the community. The table reveals that $54 \%$ or 19 of the respondents most wanted to sponsor a scholarship program for those students who want to engage as self- supporting, student aid, and interns.

\section{Introduction:-}

Corporate Social Responsibility, defined by the World Business Council for Sustainable Development (WBCSD), is "the continuing commitment by business to behave ethically and contribute to economic development while improving the quality of life of the workforce and their families as well as of the local community and society at large". In this way, the central intent of social sustainability is to promote the public good by supporting the social sector - this is its raison d'être. Without serving the social sector, a social programme could not make this classification and would simply be a business initiative.

Corresponding Author:-Edna P. Yumol. Address:-CPA,PhD,Kalinga State University,Tabuk City ,Kalinga,Philippines. 
Business is an active partner in social growth - improving the quality of life of the workforce and their families, local communities, and society at large. It seeks to manage the business processes to produce an overall positive impact on society. The economic downturn has led to an increase in demand and need for the services of charities.

As an employer, business creates social value through providing employment. The level of social contribution is affected by the conditions the organization creates as an employer. For example, the approach toward, among other things; training, diversity, employee share ownership, stress management, respect, fairness, flexibility, remuneration, and ethics. As a consumer, business also provides economic and social value within the supply chain. The level of social contribution is influenced by the approach taken toward labour standards, payment levels and terms, geographic sourcing, enforcement of supply chain standards. The businesses provide social value through paying taxes.

As a producer, business creates social value through providing goods and services to meet human needs. The level of contribution depends upon the social purpose of the goods and/or service, the approach taken to positioning nonnecessary goods (use of pressure to over-consume), responsible advertising, approach toward environmental impact of goods (e.g. resource efficiency, environmental technology).

Addressing widespread poverty is the single most important policy challenge facing the Philippines. Not only is poverty high when benchmarked against countries in Asia, but also the rate of poverty reduction has been slow. While the Philippine economy has grown at an average of 6 percent for the last five consecutive quarters (since 2012), poverty incidence remains above 20 percent of the population. The critical challenge is to spread the payback of this huge economic turnaround among the people, especially the poorest of the poor. They should feel the benefits of the growing Philippine economy, OECD (2009) report.

Entrepreneurship can provide the solution by creating wealth, jobs, and social empowerment. If we are to address the issue of poverty with some degree of success, history tells us we have no choice but to actively encourage entrepreneurial ventures.

Poverty has been falling, but at a glacial pace; this motivates the search for measures to accelerate growth, and increase the social impact of growth. Based on the alternative international lines, poverty has been falling, though the rate of change has been slow (an average of 0.8 percentage points per year); there was in fact an episode of poverty increase (2009 - 2012). The country will likely miss its Millennium Development Goal (MDG) target of halving poverty from $1990-2015$. This highlights the necessity of accelerating the pace of poverty reduction, not only by increasing the rate of overall growth, but by spreading out that growth to the base of the pyramid. Within the $\mathrm{BoP}$ is the subset of households who count as poor based on the official line; accordingly, this line is about $9 \%$ above the international subsistence line. Households under the official line account for a little more than a quarter of the population.

\section{Significance of the Study}

This study focused on the status of business enterprises as private entities of the economy and its role in poverty alleviation to the Filipino people. It is therefore important to know how aware is the business establishment owners of their social responsibilities in the community and to the public.

\section{Review of Related Literature}

The most recent legislative incentive to incorporate ethics in the corporation came in the Sarbanes-Oxley Act of 2002, passed as a result of a rash of scandals involving Enron, WorldCom, Arthur Andersen and other prominent corporations. The Act requires, among other things, that the CEO and CFO certify the fairness and accuracy of corporate financial statements (with criminal penalties for knowing violations) and a code of ethics for the corporation's senior financial officers, as well as requiring a great deal more public disclosure(https://www.scu.edu/ethics/focus-areas/business-ethics).

\section{Social Responsibility and Business Ethics}

The language of social responsibility rather than explicit ethical language is still probably the most commonly used. Self-monitoring of adherence to a corporation's stated principles and self-adopted standards are becoming more common, and some companies have voluntarily adopted monitoring of their practices, policies and plants by independent auditors. The notion of a Triple Bottom Line, which involves financial, social and environmental 
corporate reporting, has been adopted by a number of companies. Other popular reporting mechanisms include corporate environmental sustainability reports and social audits, which vary considerably in what is reported and how it is reported. Ethical investing is another aspect of the movement, and managers of ethical investment funds have begun proposing stockholder proposals as a means of encouraging more ethical behavior on the part of corporations in which they own stock.

Social responsibility and business ethics often regard as the same concepts. However, the social responsibility movement is but one aspect of the overall discipline of business ethics. The social responsibility movement arose, particularly during the 1960s with increased public consciousness about the role of business in helping to cultivate and maintain the highest ethical practices in society and particularly in the natural environment.

Ethical behavior and corporate social responsibility can bring significant benefits to a business. (http://businesscasestudies.co.uk/c), for example, they may: attract customers to the firm's products, thereby boosting sales and profits, make employees want to stay with the business, reduce labor turnover and therefore increase productivity, attract more employees wanting to work for the business, reduce recruitment costs and enable the company to get the most talented employees, attract investors and keep the company's share a high price, thereby protecting the business from takeover.

\section{Corporate social responsibility}

Corporate social responsibility (CSR) refers to business practices involving initiatives that benefit society. A business's CSR can encompass a wide variety of tactics, from giving away a portion of a company's proceeds to charity, to implementing "greener" business operations. There are a few broad categories of social responsibility that many of today's businesses are practicing(Business News Daily-2016). There are a few broad categories of social responsibility that many of today's businesses are practicing: Environmental efforts, Philanthropy, Ethical labour , and practices Volunteering.

A strong economy is based on the performance of business because business effects the entire economy. Business success raises revenues for the government and contributes economic improvement of the local, regional, and national Budget from their tax payment and financial supports to community projects.

\section{Roadmap towards Achieving Economic Growth and Environmental Integrity}

Since large or small businesses are part of the sectors of a country, the owners should take note of the programs of programs like the 1987 Philippine Strategy for Sustainable Development (PSSD). The PSSD represents the country's first roadmap towards achieving economic growth and environmental integrity-the twin pillars of sustainable development (SD) in the 1980s. It was not until ten years later, when the Philippine Agenda 21 (PA21): A National Agenda for Sustainable Development for the 21th Century was written in response to the 1992 Earth Summit in Rio de Janeiro, that social development became the third pillar of sustainable development. Thus, apart from providing enabling economic and environmental policies and integrating the idea of sustainable development into the country's governance framework, the action agenda of PA21 specifically highlighted investments in human and social capital, health, population management, and human settlements, while recognizing the need to address the poverty of communities in forest-watershed, agricultural, coastal/marine, and urban ecosystems (PSSD -1987).

\section{Importance of Industrialization}

Without doubt, industrialization must be pursued. It is the vehicle through which we expect to solve problems of mass poverty and unemployment. However, industry withdraws materials from the natural resource base and generates pollution. Depending on the overall framework of the policy to be adopted, industrialization has the power either to enhance or degrade the environment (http://www.psdn.org.ph/agenda21/pssd.htm).

The industrial sector registered a positive gross value added (GVA) of $8.02 \%$ in 1987. Growth was principally attributed to the renewed business confidence in the economy due to the improved consumer spending and perceived political and economic stability.

The growth in the industrial value-added accounted for by improved performance in manufacturing (7.12) and electricity, gas and water subsectors (10.74). A strong domestic expenditure program, stable consumer prices and a demand for manufactured export products in the world market enhanced the growth of manufacturing industries. 
Increases in the growth level of the electricity, gas and water subsector can be attributed to the higher consumption of power and water by commercial and industrial firms.

In terms of regional capital investment, the National Capital Region and Southern Tagalog registered a 95 percent increase in paid up capital stock of existing and new domestic stock corporations.

\section{Philippine Corporate Social Responsibilities Compliance \\ The case of FILINVEST in Cebu}

In order to sustain development, every sector of the country should participate in the achievement of sustaining the environment as well as social development. If students are mandated to obey the laws of the environment, then the other sectors should be the first to comply most especially those income generating establishments.

In the Philippines, it has been observe that business sectors are being recognized because of their accomplishment to their responsibility to the environment, like Clariden Holdings, Inc, CHI is implementing its Environmental Protection and Enhancement Program, Fine Mine Rehabilitation and/or Decommissioning Program, and Environmental Work Programs in Surigao City and Camarines Norte, where its mining facilities and operations are located, by the establishment of an Eco-Park and Wildlife Sanctuary and the rehabilitation of mined out areas in Nonoc Island, Surigao City, the reforestation of a 20-hectare area in Barangay Villa San Isidro, Sta. Elena, Camarines Norte, fresh water, air, and marine quality monitoring, Asbestos Containing Materials Management, Solid Waste Management, and Hazardous Waste Management, among others. All these efforts account for CHI's share in its responsibility for environmental protection and sustainable development. These actions are supporting the environmental protection program of the government embodied in the rule of law of the business company.(http://www.topfrontier.com.ph/). The following are some programs of CHI that extended their support to the government programs.

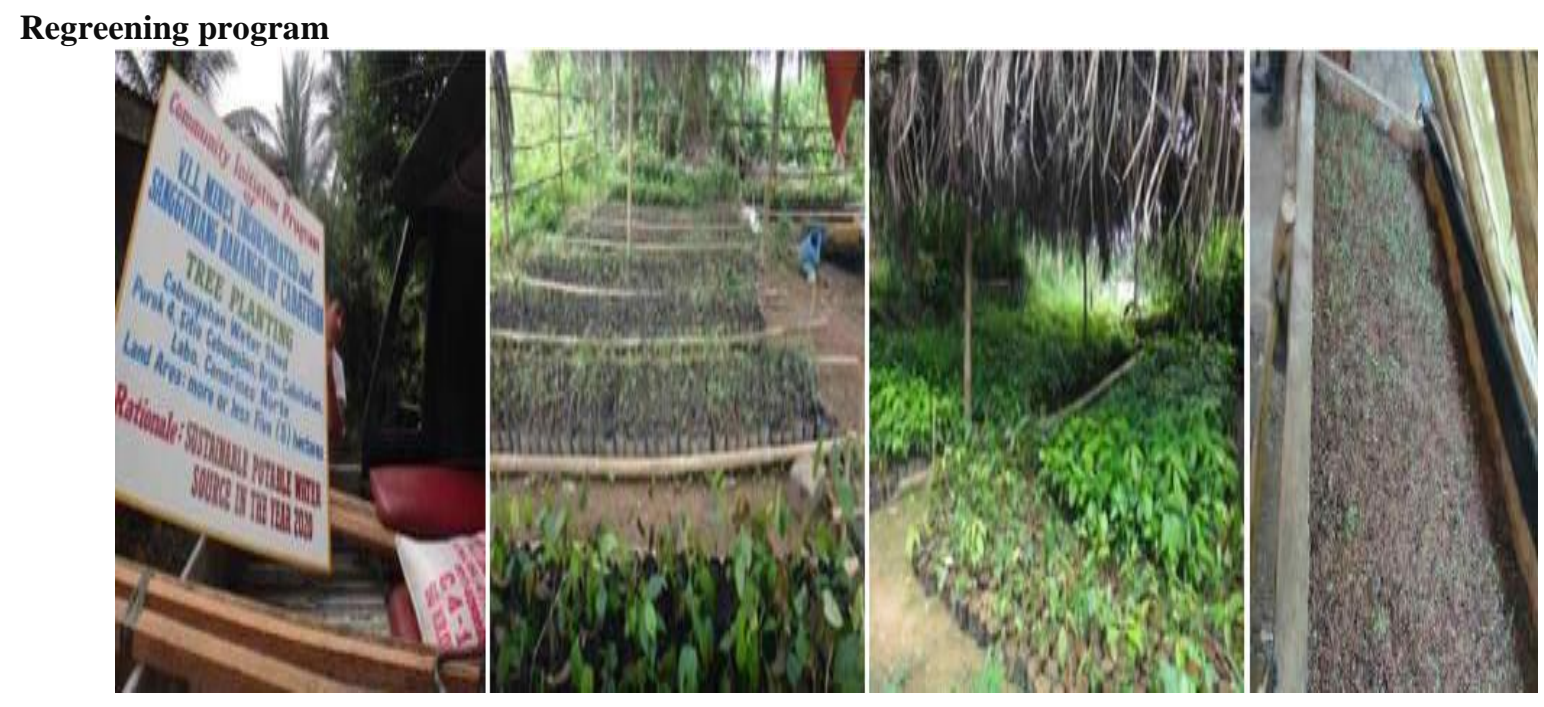




\section{Educational Assistance}

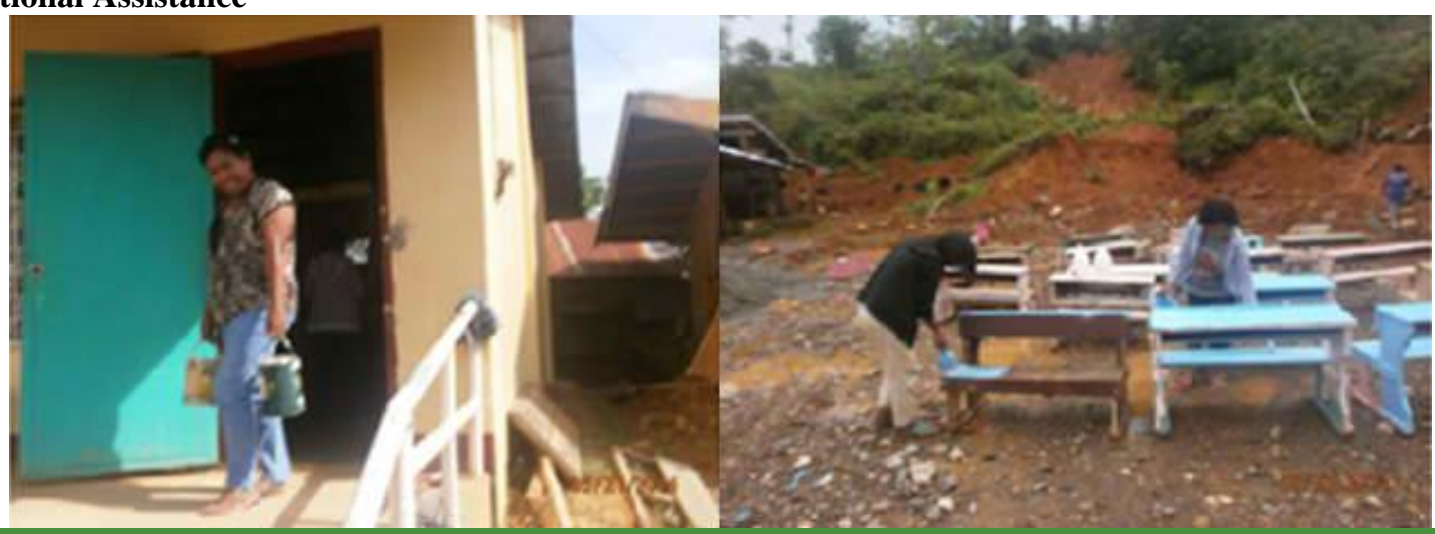

Construction of School Arc with Steel Gate, Stairs, and Perimeter Fencing of School to ensure the safety of the students in Hanigad Island, Surigao City

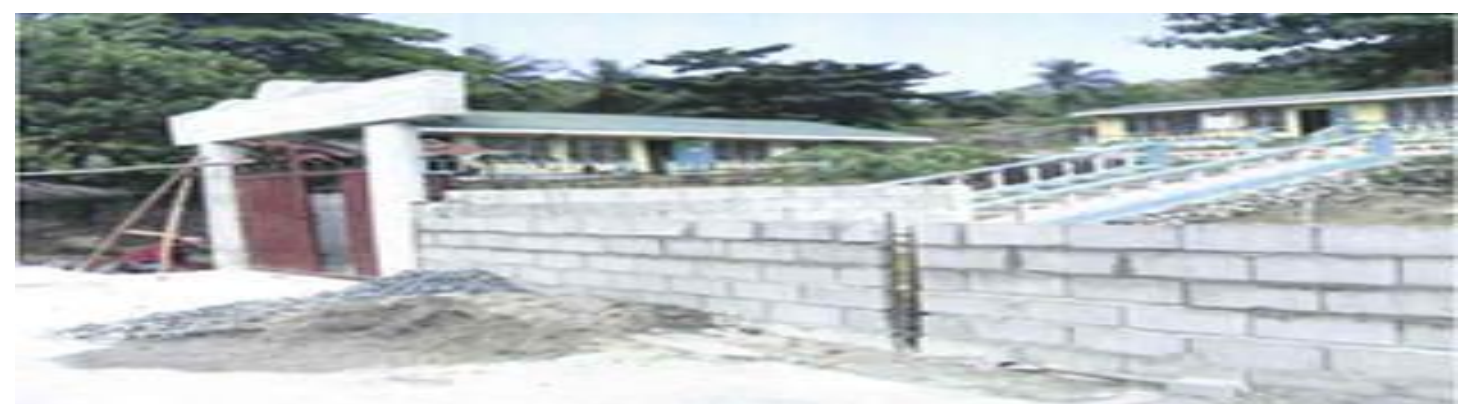

Provision of Materials for DepEdS'

Fig 1:-

According to FILINVEST ,Working towards the vision of a sustainable future, FLI continued its "Keep It Green" tree-planting initiative, which seeks to increase the number of native Philippine trees in the Company's project sites. The third annual tree-planting activity saw the simultaneous planting of 892 native tree seedlings in various FLI project sites in June 2015, which was joined by employees, sellers and homeowners. All proceeds of the event were donated to the Kanlungan ni Maria Home for the Aged. Numerous seedlings were also planted in Austine Homes, Pampanga, and in various locations around Havila, Timberland Heights and Filinvest City.

FLI employees joined Filinvest Run for a Child 2016, the culminating activity for the celebration of Filinvest's $60^{\text {th }}$ year in business. More than 1,000 runners participated in the charity run which was held for the benefit of the scholars of the Educational Research and Development Assistance (ERDA) Foundation. A total of Php6 million was donated to ERDA from the Filinvest Corporate City Foundation and the Andrew Gotianun Foundation.

In Cebu, The Company teamed up with the Lapu-Lapu City government and barangay Agus rehabilitate 10 classrooms before classes opened in June 2015. FLI employees joined the teachers, parents and city hall personnel in this activity as part of the Brigada Eskwela initiative of the Department of Education

FLI head office employees reached out to orphans and the elderly in their annual Christmas outreach program. In 2015, they brought holiday cheer and gift packs to the wards of House of Refuge Foundation in Quezon City and Kanlungan ni Maria in Rizal.

In Cagayan de Oro, FLI conducted a Christmas outreach program at the House of Joshua, a residential home for abandoned, orphaned and neglected street children. It has its own learning center to facilitate education through play and interaction as well as formal learning and vocational training. Volunteer teachers and staff facilitated the various activities designed to encourage the children to reach their full potential.

FLI also supports worthwhile causes in partnership with the community stakeholders. Festival Mall joined forces with Muntinlupa's local government offices, NGOs, I Can Serve, and Asian Hospital Foundation, Inc. for "Go 
Pink," a campaign to promote breast cancer awareness and early detection. The campaign earned Festival Mall three Silver Awards during the $52^{\text {nd }}$ Anvil Awards.

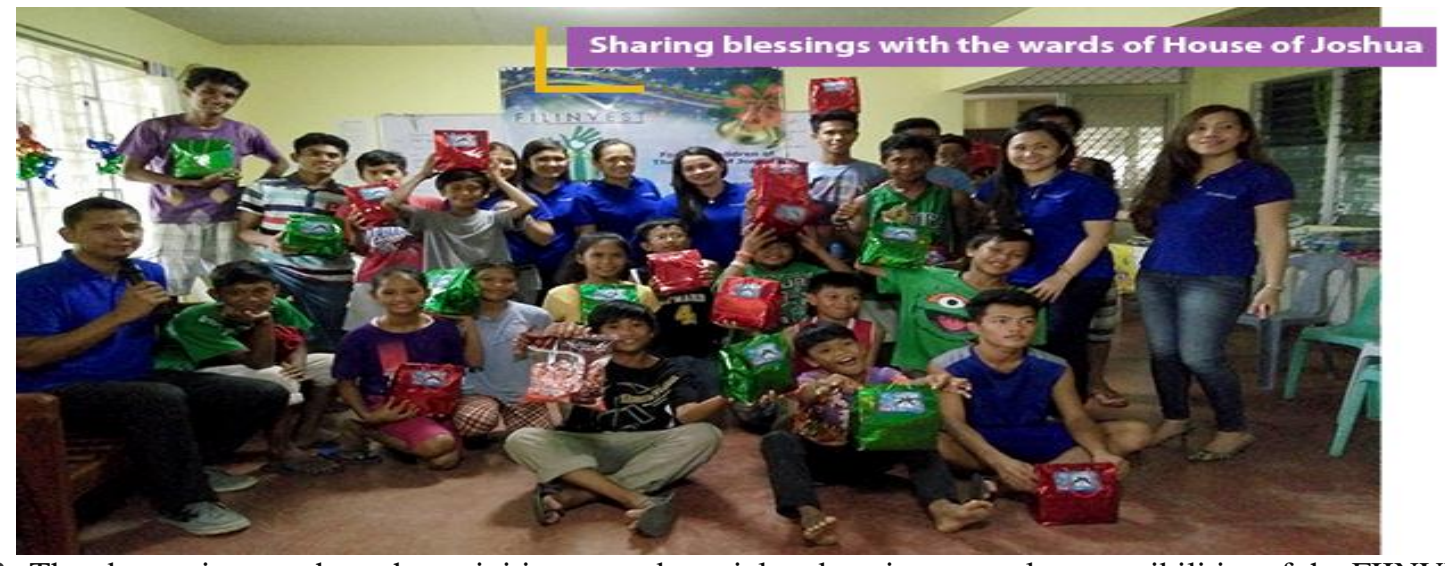

Fig 2:-The above pictures show the activities towards social and environmental responsibilities of the FIINVEST to the government of Cebu City. This supports the present study and it helps the reader to know that there are still lots of ways to help the poor in the back areas of the Philippines.

\section{The Case of Davies Paints Philippines in Benguet}

In Balili, La Trinidad, Benguet according to Sunstar Newspaper: several agencies, groups, and organizations collaborated for the realization of the ambitious project. Davies Paints Philippines, Inc. provided all of the paints for free. A thousand gallons of primer paints and five-hundred gallons of colored paints were already used. This is not to mention the 1,300 gallons that are yet to be used. That's a total of 2,800 gallons of paint. Valred Olsim, Tourism Officer of La Trinidad, estimates that Davies Paints donated about two million pesos worth of paint for the project.

Residents of Balili and volunteers from various groups did the dirty work of painting the houses. There's Gloria Agasen who led the Balili community and there's Chris Alangdeo, the chief painter. Volunteer organizations that lend a hand in the project include the Boy Scouts of the Philippines (Benguet Chapter), NSTP students from the Benguet State University, NSTP students from the King's College of the Philippines, the Botiwtiw Women's Brigade and Organization, the Baguio-Benguet Photographers Hikers and Artists Club, and police trainees from the Philippine National Police: Cordillera Administrative Region. Free meals and snacks were provided for the painters and volunteers by Cara Cosalan.

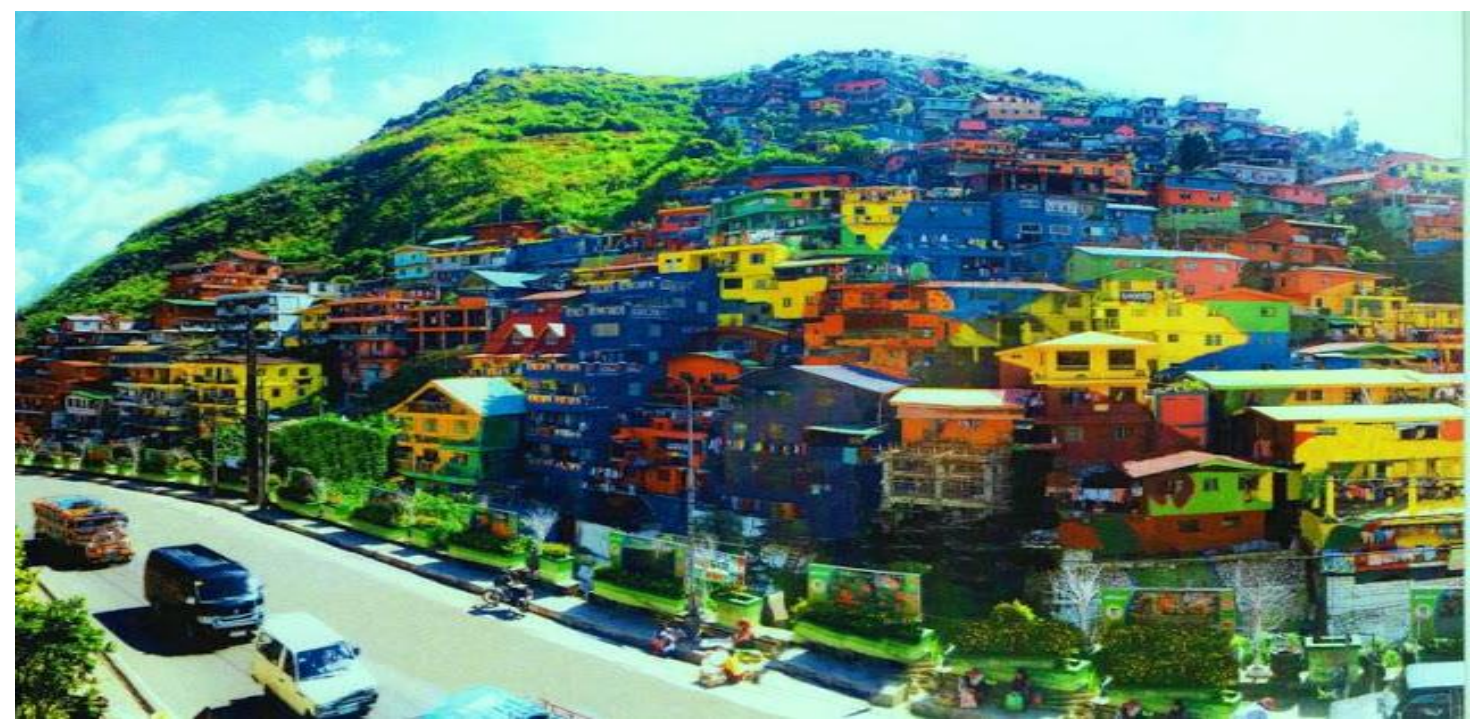

Fig 3:-The project contributed by Davies Paints Philippines, Inc.and the works of the responsible citizens of La Trinidad, Benguet. 
The Case of Tabuk City Business Establishments

In Tabuk City, three businesses were awarded bronze seal for their compliance to fair trade laws and maintaining a consumer welfare desk, and one awarded the silver seal for complying the requirements to social responsibilities. Likewise, the Department of Trade (DTI) and Industry awarded during the inter-agency at City Hall Silver Bagwis Seal to K-Servico Trade ,Inc. for its unwavering support in upholding consumer rights and ethical business practices and other social responsibilities.

In addition to the above information, there were eleven business establishments in the province have enrolled in the 'Diskwento: Presyong Panalo Para sa Mamimiling Pilipino' program in the province.

The participating stores in the province are T. Bayle Supermart Bulanao, Flory Mencero Grocery, Take That Grocery, Casigayan Store, Fairprice Trading, NE's Paper Hause and General Merchandise, Edlen's Dry Goods, Shamir Da Lims Hardware and General Merchandize, Malabong Construction Supply, CD Midtown Hardware and Paint Center, and Bongdoen Hardware and General Merchandise.

The Department of Trade and Industry (DTI) Kalinga Provincial Director Grace Baluyan said the enrolled establishments in the province have adopted various schedules schemes within the period May to December 31, this year.

The project proposed to offer the discount program for school supplies from May to June, while the basic necessities and prime commodities, and construction materials will run from May to October this year.

For the public to be able to identify the participating stores, proprietors, she said, are required to install a “Diskwento: Presyong Panalo Para sa Mamimiling Pilipino' signage outside their stores and set up an area inside their establishments to display the discounted goods for the public's easy access.

The program, which is an adoption of the 2011 In-store Diskwento scheme of the agency, according to Baluyan, has three objectives.

First is to empower consumers by making available to them quality, but discounted goods in retail stores. Second is to encourage retailers to sell commodities within or below the suggested retail price promoting a sense of social responsibility in the business sector, and third is to promote the program as a brand symbolizing public-private partnership.

The above mentioned social responsibility supports the purpose of this study. Since this study also looked into the assessment of business responsibilities of the business owners towards their employees, customers, and the community.

\section{Conceptual Framework}

This study was conceptualized based on the theories of CSR: CSR is interpreted in many ways by different authors and theories that attempt to explain what it is just as diverse. Garriga and Melé (2004) identified four categories of CSR theories, namely: instrumental theory, political theory, integrative theory, and, ethical theory.

The Instrumental theory postulates that a corporation is nothing but an instrument for the creation of wealth. Examples of theoretical approaches pertaining to category include Friedman's shareholder theory (Freidman, 1962); the strategic approach advocated by researchers such as Prahalad and Hammond (2002); and the Hart (1995) resource-based approach. Political theory focuses on the influence that corporations have on the political system of the country or region in which they operate. Proponents of this theory include David (1960) who advocated corporate constitutionalism; and Matten and Crane (2005) who advocated Corporate Citizenship, a theory that seeks to explain why corporations need to act as responsible citizens of the community where they reside and conduct their businesses. As its name suggests, integrative theory promotes the integration of societal concerns and demands into a corporation's business strategy and processes. One of the champions of this theory was Selznik, who as early as 1957 was already advocating community obligation as a business-success imperative. More recent theorists falling under this category include Jones (1980), with his social obligation approach, and Wood (1991) who argues that corporations must perform well on societal-obligation metrics if they are to succeed. Last but not least, there is an ethics-based theory, which advocates ethical responsibilities of corporations towards society. Modern theorists 
supportive of this school of thought include Hancock (2005) and Pettit (2005) who have made noteworthy contributions to the understanding of CSR in modern times. Also worth mentioning in this category is the normative approach advocated by Epstein (1987) and Smith (2003). Of the many other theories existing today, three are more widely accepted and are the ones this research will focus on; these are: Stakeholder theory, Legitimacy theory, 2.1.1 Stakeholder Theory Given the amount of attention and interest it has been receiving in recent years, particularly in the area of business ethics, stakeholder theory is arguably the most important CSR theory of today. The theory is grounded on paying due attention to the needs, rights and interests of multiple stakeholders and seeking effective ways of meeting those needs, rights and interests. Common ways of achieving this include appropriate public and economic policy formulation and the mapping out of supportive corporate strategies (Greenwood, 2001; Dawkins and Lewis, 2003; Maignan and Ferrell, 2004). As Solomon (2010, p. 15) puts it, stakeholder theory may be viewed as a "conceptual cocktail, concocted from a variety of disciplines and producing a blend of appealing sociological and organizational flavours". In this regard, therefore, Solomon (2010, p.16) sees CSR as becoming an increasing major concern for companies in today's political and social climate, noting that social and environmental lobby groups are relentlessly pressuring companies to improve their attitudes towards stakeholders by acting in a socially responsible man.

The above theories are important in the pursuit of CSR studies and practices of the concerned agency as well institution for which the Kalinga State University as a higher public institution should look into the CSR assessment in order to help educate the business sectors through the academic extension services of the College of Business Administration.

\section{Statement of the Problem}

The role of business enterprise in the economy is not just to make money or profit, but it should be one agent to enhance the living conditions of its clients and the community. This study generally aims to look into the specific roles of businesses in the different sectors of the society and in the economic improvement of the people's standard of living.

\section{Objectives of the Study}

To determine the level of practices of business owners towards their social responsibilities to their employees and the consumers;

\section{Hypotheses:}

1. There is a significant relationship between the size of income and the level of practice towards the social responsibilities of the businesses (the respondents) to their employees.

2. There is a significant relationship between the size of the businesses and the level of practice towards the social responsibilities of the businesses(the respondents) to their consumers.

3. There is a significant relationship between the amount of tax due and the level of practice towards the social responsibilities of the businesses (the respondents) to their consumers.

To the level of participation of the business establishments towards their responsibilities to the community perceived by the local officials;

\section{Hypothesis:}

1. There is a significant relationship between the size of business Income and the level of participation of the business towards their responsibilities to the community.

2. To identify what project or program do respondents want to extend to the community

\section{Methodology:-}

The descriptive method was used to conduct this study through the use survey questionnaire to seek the data on the profile of the businesses, their practices and participation in their social responsibilities.

\section{Respondents}

The respondents are 35 businesses, 18 small businesses, 10 medium business, and 7 big businesses situated in Dagupan and Bulanao, Tabuk City, Kalinga,Philippines. It also included 30 local officials to respond on how frequency do the businesses participate in community projects. 


\section{Instrumentation}

Since this study used quantitative technique, a set of questionnaire was used to gather the important information to satisfy the needs of the study. The questionnaire was based on the items taken from the book "Ethics and Corporate Social Responsibility: Why Giants Fall authored by Ronald R. Sims " and CSR book authored by David Crowther.

\section{Data gathering}

The respondents were given three to 5 days to complete the data asked in the questionnaire..

\section{Data Treatment}

The data were tallied to summarize the profile of the respondents and the responses were tabulated using the 3-point scale for the practices and participation towards their social responsibilities.

\section{Statistical Treatment}

The frequency table was constructed to present the profile of the respondents, while the weighted and Chi-square was used to analyze the frequency of practices and participation of the respondents towards their social responsibilities to their employees, consumers, and the government programs handed to the community.

\section{Results and Discussions:-}

Table 1:-Present the Practices of the Respondents towards their Social Responsibilities to the Employees and Consumers

\begin{tabular}{|l|l|l|}
\hline Social Responsibilities to the Employees & $\begin{array}{l}\text { Weighted } \\
\text { Mean }\end{array}$ & Description \\
\hline $\begin{array}{l}\text { 1.Respect the rights of workers and other employees and take appropriate } \\
\text { measures to ensure their safety } \\
\text { and to improve their working conditions }\end{array}$ & 3.00 & $\begin{array}{l}\text { Often } \\
\text { Practiced }\end{array}$ \\
\hline $\begin{array}{l}\text { 2. Provide quality healthcare to their employees } \\
\text { 3. Provide regular and fair pay and benefits to their employees; }\end{array}$ & 2.86 & $\begin{array}{l}\text { Often } \\
\text { Practiced }\end{array}$ \\
\hline 4. Practice harmonious relationship with their employees / wage earners & 3.00 & $\begin{array}{l}\text { Often } \\
\text { Practiced }\end{array}$ \\
\hline Area Mean & 2.84 & Practiced \\
\hline
\end{tabular}

\begin{tabular}{|l|l|l|}
\hline Responsibilities to Consumers & $\begin{array}{l}\text { Weighted } \\
\text { Mean }\end{array}$ & Description \\
\hline 1.To supply the goods at reasonable price. & 2.57 & $\begin{array}{l}\text { Often } \\
\text { Practiced }\end{array}$ \\
\hline $\begin{array}{l}\text { 2.To provide after sales service } \\
\text { adverse effect }\end{array}$ & 1.97 & Sometimes \\
\hline 4.To ensure that the goods are fresh and not expired & 1.60 & $\begin{array}{l}\text { Seldom } \\
\text { Practiced }\end{array}$ \\
\hline 5.To avoid misleading product advertisement & 2.74 & Often Practiced \\
\hline $\begin{array}{l}\text { 6.To entertain queries and complaints from customers } \\
\text { with proper approach }\end{array}$ & 1.69 & Seldom Practiced \\
\hline $\begin{array}{l}\text { 7.To accommodate request of purchase from } \\
\text { customers and observe honest packaging of the product }\end{array}$ & 2.89 & Often Practiced \\
\hline Total Average Weighted Mean & 2.94 & Often Practiced \\
\hline
\end{tabular}

The table shows that as to the practice of the respondents(businesses) on the social responsibilities towards their employees as "often practice with an area mean of 2.84.Among the four indicators, the item which says "Respect the rights of workers and other employees and take appropriate measures to ensure their safety and to improve their working conditions "and Practice harmonious relationship with their employees / wage earners, ranked Ist with a weighted mean of 3.00.This is followed by items: "Provide quality healthcare to their employees" and "Provide regular and fair pay and benefits to their employees "with weighted means of 2.86 and 2.49 which are noted as "often practice." On the other hand, the respondents noted that in their responsibilities towards the consumers, the 
noted as "often practice" with an area mean of 2.34. Specifically, the item 7 which states that "To accommodate request of purchase from customers and observe honest packaging of the product" rank Ist and is noted as "often practice." This is followed by item no.6 which says" To entertain queries and complaints from customers with proper approach," To ensure that the goods are fresh and not expired", "to supply the goods at reasonable price," are also noted as "often practice, "While the rest: To provide after sales service, To avoid misleading product advertisement, and To ensure that the products supplied has no adverse effect are noted as sometimes and seldom practice respectively.

With this assessment, it is amazing that the respondents are following the ethical theory of business. Thus, the findings of this study complies with Matten and Crane (2005) who advocated Corporate Citizenship, a theory that seeks to explain why corporations need to act as responsible citizens of the community where they reside and conduct their businesses. As its name suggests, integrative theory promotes the integration of societal concerns and demands into a corporation's business strategy and processes. One of the champions of this theory was Selznik, who as early as 1957 was already advocating community obligation as a business-success imperative.

Table 2:-Present Whether there is a Significant Relationship between the Amount of Tax Due and the Practice of the Respondents (Businesses) towards their Responsibilities to Employees.

\begin{tabular}{|l|l|l|l|l|}
\hline \multirow{2}{*}{ Tax due } & \multicolumn{2}{l|}{$\begin{array}{l}\text { Practice of the respondents (businesses) towards their responsibilities } \\
\text { to employees. }\end{array}$} & \multirow{2}{*}{ Total } \\
\cline { 2 - 5 } & $(3)$ & $(2)$ & $(1)$ & \\
\hline High Tax & 5 & 1 & 0 & 6 \\
\hline Average Tax & 12 & 6 & 0 & 18 \\
\hline Low Tax & 2 & 7 & 4 & 11 \\
\hline Total & & & & 35 \\
\hline
\end{tabular}

Chi-square $($ computed $)=3.75$; Chi-square(.05,4)=9.35;Decision: Accept Null Hypothesis

The table reveals the result of Chi-square of $\mathbf{3 . 7 5}$ which is lower than the Chi-square tabular value of $\mathbf{9 . 3 5}$, at0.05 level of significance, degrees of freedom 4. This means that the null hypothesis which states that there is no significant relationship between the tax due and the practice of the respondents on their social responsibilities is accepted. This connotes that, regardless of the amount of tax paid by the business, they are obligated to sustain their relationship with their employees.

Table 5 Present Whether there is a Significant Relationship between the Size of Income and the Practice of the Respondents (Businesses) towards their Responsibilities to Consumers.

Table 3:-Present Whether there is a Significant Relationship between the Amount of Tax Due and the Practice of the Respondents (Businesses) towards their Responsibilities to Consumers.

\begin{tabular}{|l|l|l|l|l|}
\hline \multirow{2}{*}{ Size of Income } & $\begin{array}{l}\text { Practice of the respondents (businesses) towards their } \\
\text { responsibilities to consumers }\end{array}$ & Total \\
\cline { 2 - 5 } & $(3)$ & $(2)$ & $(1)$ & \\
\hline High income & 3 & 4 & 2 & 9 \\
\hline Average Income & 2 & 3 & 11 & 16 \\
\hline Low Income & 1 & 9 & 0 & 35 \\
\hline Total & 6 & 16 & 13 & 35 \\
\hline
\end{tabular}

Chi-square $($ computed $)=18.65$; Chi-square $(.05,4)=9.35$; Decision: Reject Null Hypothesis

The table reveals the Chi-square (computed) $=18.65$ is greater than the Chi-square $($ tabular $)=9.35$ at .05 , df $=4$. This led to the rejection of the null hypothesis that there is no significant relationship between the practices of the respondents on their responsibilities towards their consumers and the level of income. This implies that there is a significant relationship between the practices of the respondents on their responsibilities towards their consumers and the level of income. This simply denotes that the businesses can offer satisfactory services to the consumers as their income increases. The increase in the income of the businesses motivates them to serve the needs of their clients. Otherwise, whether they don't have increase in income they must sustain their services to convince more customers. 
Table 6:-Present Whether there is a Significant Relationship between the Amount of Tax Dues and the Level of Practice by the Respondents (Businesses) towards their Responsibilities to Consumers

\begin{tabular}{|l|l|l|l|l|}
\hline \multirow{2}{*}{ Amount of Tax Dues } & \multicolumn{2}{|l|}{$\begin{array}{l}\text { Practices by the respondents (businesses) towards their } \\
\text { responsibilities to consumers }\end{array}$} & Total \\
\cline { 2 - 4 } & 3 & 2 & 1 & \\
\hline 75,000 and above & 3 & 2 & 1 & 6 \\
\hline $50,000-74,000$ & 8 & 9 & 1 & 18 \\
\hline 25,000 and below & 5 & 5 & 1 & 11 \\
\hline Total & & & & 35 \\
\hline
\end{tabular}

Chi-square $($ computed $)=55.33$; Chi-square $(.05,4)=9.35$; Decision: significant

The table shows that the computed Chi-square of 55.33 is greater than the tabled value at .05 level of significance and degrees of freedom of 9.35. Thus the null hypothesis which says that there is no significant relationship between the amount of tax dues and the level of practice of the respondents (businesses) towards their responsibilities to consumers is rejected. Then, the findings imply that there is a significant relationship between the amount of tax dues and the level of practice of the respondents (businesses) towards their responsibilities to consumers.

Table 7:-Present the Assessment the Respondents' frequency of Participation towards their Responsibilities to the Community as perceived by the Local Officials.

\begin{tabular}{|l|l|l|}
\hline Responsibilities towards the Community & Mean & Description \\
\hline 1. Taking steps to prevent pollution & 2.35 & OftenParticipated \\
\hline $\begin{array}{l}\text { 2. Contribute to welfare activities like sponsoring scholarships of poor but } \\
\text { deserving students }\end{array}$ & 2.34 & Often Participated \\
\hline 3. Participate in community projects through Cash or in kind donations & 2.45 & $\begin{array}{l}\text { Often } \\
\text { Participated }\end{array}$ \\
\hline 4. Volunteer to contribute development of Backwards areas & 2.50 & $\begin{array}{l}\text { Often } \\
\text { Participated }\end{array}$ \\
\hline 5. Promote the Clean and Green Marketing & 1.90 & Participated \\
\hline 6. Participate in the government Programs & 2.48 & $\begin{array}{l}\text { Often } \\
\text { Participated }\end{array}$ \\
\hline $\begin{array}{l}\text { 7. Contribute to the economic development of the community by } \\
\text { sponsoring livelihood projects for women, and out of school youth }\end{array}$ & 2.46 & $\begin{array}{l}\text { Often } \\
\text { Participated }\end{array}$ \\
\hline $\begin{array}{l}\text { Area Mean } \\
\text { Often } \\
\text { Participated }\end{array}$ \\
\hline
\end{tabular}

As to the responsibilities of the respondents to the community, the table shows that they noted as "Often participated" with an area mean of 2.35. Most of the indicators were marked as "often practiced." However, in the indicator 5 which says "Promote the Clean and Green Marketing," it was noted as "participated" with a mean of 1.90. This finding is supported by the David (1960) who advocated corporate constitutionalism; and Matten and Crane (2005) who advocated Corporate Citizenship, a theory that seeks to explain why corporations need to act as responsible citizens of the community where they reside and conduct their businesses.

Table 8:-Present Whether there is a Significant Relationship between the Business Income and the Participation by the Respondents (Businesses) towards their Responsibilities to Community

\begin{tabular}{|l|l|l|l|l|}
\hline Income & \multicolumn{2}{|l|}{$\begin{array}{l}\text { Participation by the respondents (businesses) towards their } \\
\text { responsibilities to community }\end{array}$} & Total \\
\hline High Income & 3 & 4 & 2 & 9 \\
\hline Average Income & 2 & 11 & 3 & 16 \\
\hline Low Income & 5 & 5 & 2 & 10 \\
\hline Total & & & 35 \\
\hline
\end{tabular}

Chi-square (computed) $=2.16$; Chi-square $(.05,4)=9.35$;Decision: Accept Null Hypothesis

The table reflects that the Chi-square computed which is 2.16 is lower than the tabled value of Chi-square at 0.05 level of significance with df-4 which is 9.35 . This test result made the null hypothesis which says that there is no 
significant relationship between the business income and the participation by the respondents (Businesses) towards their responsibilities to the community is accepted. Then, it can be said that there is a significant relationship between the business income and the participation by the respondents (Businesses) towards their responsibilities to the community. This finding denotes that whether the income of the business is enough, they should extend and sustain supports to the community.

Table 9:-Present the Responses of the Respondents when they were asked on What Project or Program Do They Want to Extend to the Community

\begin{tabular}{|r|l|l|}
\hline Suggestions & Frequency & Percentage \\
\hline $\begin{array}{l}\text { Sponsor scholarship to poor student, e.g. Self-supporting } \\
\text { students, part time job, student assistant, and interns. }\end{array}$ & 19 & 54 \\
\hline 2. Livelihood project for out of school youth & 8 & 23 \\
\hline 3. Sponsoring Research and Extension Activities & 2 & 6 \\
\hline 4. Sponsor training activities for women's project & 4 & 11 \\
\hline 5. No response & 2 & 6 \\
\hline$\quad$ Total & 35 & 100 \\
\hline
\end{tabular}

The table reveals that $54 \%$ or 19 of the respondents wanted to sponsor a scholarship program for those students who want to engage as a self supporting, student aid, and interns. While $23 \%$ or 8 of them wanted to sponsor a livelihood project for out of school youth. Seventeen (17) \% or 6 of them wanted to sponsor for a women's livelihood project. Only 2 of them wanted to sponsor research and extension activities. And there were two of them who did not respond at all.

\section{Summary of Findings}

In the responsibilities of businesses to employees and consumers, The table shows that as to the practice of the respondents(businesses) on the social responsibilities towards their employees as "often practice with an area mean of 2.84.Among the four indicators, the item which says "Respect the rights of workers and other employees and take appropriate measures to ensure their safety and to improve their working conditions "and Practice harmonious relationship with their employees / wage earners, ranked Ist with a weighted mean of 3.00.This is followed by items: "Provide quality healthcare to their employees" and "Provide regular and fair pay and benefits to their employees "with weighted means of 2.86 and 2.49 which are noted as "often practice."

As to the assessment of the respondents for their participation towards their responsibilities to the community, the table shows that they noted as "often participated" with an area mean of 2.35. Most of the respondents noted that they often practice the different responsibilities towards the community.

As to the relationship between the business income and the participation by the respondents (businesses) towards their responsibilities to the community, it was tested that there is no significant relationship between the business income and the participation by the respondents (Businesses) towards their responsibilities to the community is accepted.

As to the responses of the respondents when they were asked on what project or program do they want to extend to the community. The table reveals that $54 \%$ or 19 of the respondents most wanted to sponsor a scholarship program for those students who want to engage as a self supporting, student aid, and interns.

\section{Conclusions:-}

From the above findings, the following can be concluded:

1. That most of the businesses that were assessed has small capital, average income and average tax due; that $51 \%$ or 18 business owners in Bulanao and Dagupan ,Tabuk City said they have small capital, that $46 \%$ or 16 of the businesses (the respondents) have an average income, and that 51\% or 18 of the businesses (the respondents) have 51,000 to 99,000 pesos tax.

2. The relationship between the amount tax and size of income, it was tested and concluded that there is a significant relationship. 
3. The practice of the respondents (businesses) on the social responsibilities towards their employees is assessed to be "often practice; and that there is no significant relationship between the tax due and the practice of the respondents on their social responsibilities

4. That there is no significant relationship between the practices of the respondents on their responsibilities towards their consumers and the level of income;

5. That there is a significant relationship between the amount of tax dues and the level of practice of the respondents (businesses) towards their responsibilities to consumers;

6. That, the assessment of the respondents on their participation towards their responsibilities to the community, it was noted and assessed to be "sometimes participated" with an area mean of 2.06; and that there is no significant relationship between the business income and the participation by the respondents (Businesses) towards their responsibilities to the community;

7. That, the most of the respondents wanted to sponsor a scholarship program for the poor but diligent students.

\section{Recommendation}

From the above findings and conclusions, the following can be recommended:

1. Since most of the businesses (the respondents) have small capital, it can be recommended that the financial institutions can help them raise their capital to expand their business activities for greater profit and accommodation of customer's needs ;

2. Since the amount tax and size of income has significant relationship, the tax collections should be sustained regularly in order to maintain and increase income from businesses.

3. The responsibilities of the respondents towards the consumers should be often practiced especially in the after sales service, the advertisement regarding the effect of the product and the expirations of the product usage.

4. The business sector should be oriented with their responsibilities to the community in order that they can participate actively to contribute to the economic development of the community by sponsoring livelihood projects for women, and out of school youth and support the backward areas that the government have not reached.

5. There must be an orientation to be conducted to the business sector on the clean and green marketing in order they will be educated on how to implement and sustain it.

6. Inform to the students to apply for a scholarship or student assistant and recommend it to the sponsoring business sector;

\section{References:-}

1. Business-ethics-and-corporate-social-responsibility/what-are-business- http://businesscasestudies.co.uk/angloamerican/ ethics.html

2. Corporate Social and Environmental Reporting: a Review of Literature and a Longitudinal Study of UK Disclosure, Accounting Auditing and Accountability Journal, vol. 8, n. 2, pp. 47-77. Gray, R... Kouhy, R. and Lavers, S. (1995b).

3. David Crowther (2012) . Corporate Social Responsibility 2012international journal of research in commerce, it \& management - ijrcm.org.in/download.php?name=ijrcm-4-Ivol-2_issue

4. Dirk Matten \& Andrew Crane. Corporate Citizenship: Towards an extended theoretical conceptualization. The International Centre for Corporate Social Responsibility Nottingham University Business School Nottingham University. No. 04-2003 ICCSR Research Paper Series - ISSN 1479-5124

5. Ernst and Ernst, Epstein, E. M. (1987).The corporate social policy process: beyond business ethics, Corporate Responsibility, and Corporate Social Responsiveness. California Management Review 29(3), 99-114.),

6. Gray, R... Kouhy, R. and Lavers, S. (1995) Corporate Social Responsibility Theories: mapping the territory. Journal of Business Ethics 53(1-2), 51-71.),

7. Greenwood, M.R. (2001). Methodological Themes Constructing a Research Database of Social and Environmental Reporting by UK Companies, Accounting, Auditing and Accountability Journal, vol. 8, no. 2, pp. 78-101. Gray, R. Owen, D. and Adams, C. (1996) Accounting and Accountability, London- Prentice Halls Inc.

8. Garriga, E , Melé, D. (2004Social Responsibility Disclosure surveys, Ernst and Ernst, Cleveland, OH. Friedman, M. (1962), Capitalism and freedom, University of Chicago Press: Chicago, IL, USA.),

9. Guthrie, J. (1983). The Community as a Stakeholder Focusing on Corporate Social and Environmental reporting. Journal of Corporate Citizenship Corporate Social Accounting and Reporting: An Australian Empirical Study. Paper Presented at the AAANZ Conference, Griffin University, Australia. 
10. Janine Palec. The Philippine Agenda 21. . . Executive Order No retrieved from http://www.psdn.org.ph/agenda21/pssd.htm. Archived Web Site PIA Information Services Philippine Information Agency ... of Congress, Washington, D.C., 20540 USA; Source Url: http://www.pia.gov.ph/ ...

11. PIA | DTI awards Bagwis seal to 4 Tabuk establishments

12. -tabuk-establishments news.pia.gov.ph/article/view/.../dti-awards-bagwis-seal-to-4

13. Richard T. De George. A History of Business Ethics retrieved from https://www.scu.edu/ethics/focusareas/business-ethics/.../a-history-of-business-ethics/

14. Skye Schooley, 2019. What Is Corporate Social Responsibility? Retrieved from http://www.businessnewsdaily.com. 